\title{
Anna Sporczyk-Popielarczyk
}

Nicolaus Copernicus University, Torun

annasporczyk@o2.pl; ORCID: 0000-0001-9204-4331

\section{Dispute over the prohibition to advertise the activity of so called pharmaceutical entrepreneur}

http://dx.doi.org/10.12775/SIT.2018.019

\section{Preliminary remarks}

In the period of free market economy, advertising is a significant instrument used by the entrepreneurs to attract customers. In the legal literature advertisement is defined as the action referring to goods or services that provides encouragement to purchase them. Legal academics and commentators indicate that the term of advertisement should be understood in a broad sense, referring them to each activity in which the incentive appears. The economic objective of the activity, i.e. the increase in the turnover of the advertised subject, constitutes the sine qua non condition so as to regard the respective activity as an advertising activity. Moreover, it should be noticed that the advertisement is defined as activity - action. Thus, the passive behaviour of the subject is not an advertisement ${ }^{1}$.

${ }^{1}$ R. Kruszyński, Podmiotowy i przedmiotowy zakres zakazu reklamy aptek $w$ znowelizowanym Prawie farmaceutycznym, "Aptekarz Polski" 2012, no 65, p. 43; R. Skubisz, in: Ustawa o zwalczaniu nieuczciwej konkurencji. Komentarz, J. Szwaja (ed.), Warszawa 2000, p. 420; E. Nowińska, M. du Vall, Ustawa o zwalczaniu nieuczciwej konkurencji. Komentarz, Warszawa 2010, p. 262. 
The Act on Pharmaceutical Law of 6 September $2001^{2}$ assumes that the subject applying for permission to run the pharmacy needs to be a pharmacist who has the right to exercise the profession mentioned in article 4 and article $4 \mathrm{~b}$ of the Act on Pharmaceutical Chambers of 19 April $1991^{3}$, running its economic activity as a sole proprietorship or a partnership ${ }^{4}$. In the light of the above regulations there are no doubts that the entrepreneur entitled to obtain the permission to run a pharmacy is an entrepreneur in the understanding of article 4 item 1 of the Entrepreneurs Law Act of 6 March $2018^{5}$. However, it is clear that a so called pharmaceutical entrepreneur ${ }^{6}$ is the facility of specific status as the pharmacy constitutes at healthcare facility at the same time, which arises from article 86 item 1 of Pharmaceutical Law. The entrepreneur running a pharmacy is subject to formal requirements different than in case of business operators rules than other economic facilities, and has to consider some legal limitations referring to its activity. To exemplify, one of such restrictions is the prohibition to advertise pharmacies $^{7}$ - included in the art 94a of the Pharmaceutical Law.

The problem of the legislator's interference into the economic freedom of pharmaceutical entrepreneurs appears to be incredibly topical due to the significant recent amendments to Pharmaceutical Law. The objective of this article is an attempt to resolve whether the prohibition to advertise pharmacies included in the provisions

2 Act on Pharmaceutical Law of 6 September 2001, "Journal of Laws" of 2001 No 126, item 1381 with amendments; hereinafter referred to as: Pharmaceutical Law.

${ }^{3}$ Act on Pharmaceutical Chambers of 19 April 1991, Unified text: “Journal of Laws" of 2016, item 1496.

${ }^{4}$ Provision of article 99 item 4 Pharmaceutical Law as amended by the Act on the Amendment of Pharmaceutical Law of 7 April 2017, "Journal of Laws" of 2017 , item 1015.

${ }^{5}$ Entrepreneurs Law Act of 6 March 2018, “Journal of Laws” of 2018, item 646.

${ }^{6}$ For the purpose of this article, the term "pharmaceutical entrepreneur" refers to the entrepreneur running a pharmacy.

7 The act uses the expression "advertising pharmacies", however, it is clear that it refers to taking advertising actions by the entrepreneur running a pharmacy. 
of Pharmaceutical Law infringes the freedom of economic activity guaranteed to each entrepreneur pursuant to the Polish Constitution. Firstly, the historical overview of the solutions included in the provision of article 94a will be presented. Secondly, the term of advertising the pharmacy, explained as a reference to its scope and forms, will constitute the starting point for the consistency analysis of the discussed regulations in view of the freedom of economic activity granted in the Constitution.

\section{Ratio legis of legal solutions adopted in Pharmaceutical Law}

Before $1^{\text {st }}$ May 2007 there was no reference to the issue of advertising the activity of a pharmaceutical entrepreneur in the Act on Pharmaceutical Law. The limitations concerning advertising of pharmacies and pharmaceutical outlets were introduced to the Polish legal system with the Act of 30 March 2007 amending the Act on Pharmaceutical Law and amending some other acts ${ }^{8}$. The amended to the Pharmaceutical Law provision of article 94a prohibited any advertising of pharmacies or pharmaceutical outlets ${ }^{9}$ addressing the public which would directly relate to medical products or medical goods placed in the lists of refunded pharmaceuticals or lists of medical products or medical goods if the name of such product(s) overlapped with the name of the medical products or medical goods placed in the lists of refunded pharmaceuticals.

The practice showed that the content of the message advertising the respective facility, at the same time not the advertisement of the medical product, might have been only the indication of such a facility's existence, its place of operation or opening hours. It was

8 Act of 30 March 2007 amending the act - Pharmaceutical Law and amending some other acts, "Journal of Laws" of 2007, No 75, item 492.

${ }^{9}$ Pursuant to article 70 of Pharmaceutical Law apart from pharmacies, pharmaceutical points may sell retail medical products. A physical person, a legal person or a commercial company without legal personality can run these points. The regulations referring to general pharmacies apply for pharmaceutical points. 
allowed to emphasise that the pharmacy offered a specifically wide range of medical products of a particular type (such as treatment shampoos or herbal medicines), as well as indicating that a given pharmacy offered a wide range of medical products coming from a particular responsible subject, which could be of significance for the patient. It was also legal to use the information directly in the advertisement that the given facility offered medical products or medicines given without doctor's prescription "more cheaply" than competitive pharmacies ${ }^{10}$.

Analysing the contents of the discussed regulation, it should be indicated that article 94a of Pharmaceutical Law did not introduce the complete prohibition to advertise but only its limitation ${ }^{11}$. However, this provision was amended with article 60 point 7 of the Act on Medicine Reimbursement, Special Purpose Food Agents and Medical Products ${ }^{12}$. The legislator introduced the complete prohibition to advertise pharmacies and their activity from 1 January 2012. Pursuant to the disposition of article 94a item 1 of Pharmaceutical Law in its current sounding, it is prohibited to advertise pharmacies and pharmaceutical outlets and their activity. The legislator excluded from the prohibition to advertise only giving (spreading) the information about the localization and opening time of a pharmacy or pharmaceutical outlet in the second sentence of the mentioned provision. The National Pharmaceutical Inspectorate supervises whether this prohibition to advertise is observed. Within the supervising competences over advertising, this authority - pursuant to article 129b of Pharmaceutical Law - has been authorised to imposed fines in the amount of up to PLN 50,000 as a result of an administrative decision.

It should be emphasised that the mentioned amendment has been broadly commented among the pharmaceutical representa-

10 M. Ożóg, System handlu produktem leczniczym i produktami pokrewnymi. Problematyka prawna, Warszawa 2010, p. 720.

${ }^{11}$ L. Ogiegło, Komentarz do art. 94a, in: Prawo farmaceutyczne. Komentarz, ed. L. Ogiegło, Warszawa 2015, Legalis.

${ }^{12}$ Law on Medicine Reimbursement, Special Purpose Food Agents and Medical Products of 12 May 2011, "Journal of Laws" of 2011, No 122, item 696 with amendments, hereinafter referred to as: the Reimbursement Act. 
tives since the moment of its passing. The government bill of the amending act did not mention the issue of pharmacies advertising, and the provision establishing its prohibition appeared while creating a separate regulation, i.e. the Reimbursement Act $^{13}$. The justification of the amendments cannot be found because the contents of article 94a of Pharmaceutical Law were changed at the stage of the work of parliamentary subcommittee ${ }^{14}$. The creators of the amendment indicated that the new provision is to contribute to the introduction of uniform prices, to the prohibition to use free market practices and to keeping the status of a pharmacy as a healthcare facility and the quality of service should be the only element of competition between pharmacies ${ }^{15}$.

Lack of explanation in the amending act on how the scope of the advertising prohibition should be interpreted results in the fact that its interpretation causes serious difficulties both for pharmacists and entrepreneurs running pharmacies as well as courts processing decisions of pharmaceutical inspectorate bodies imposing fines for infringing this prohibition ${ }^{16}$.

\section{Advertising activity of an entrepreneur running pharmacies from the perspective of judicial decisions}

There is no legal definition of pharmacy advertising in the Polish legal system. Both in the doctrine as well as judicial decisions there

${ }^{13}$ M. Kolasiński, Apteki: zakazy zamiast konkurencji, "Rzeczpospolita" of 18.11.2015.

${ }^{14}$ Konfederacja Lewiatan [Lewiatan Confederation], Wkrótce decyzja Komisji Europejskiej $w$ sprawie zakazu reklamy aptek, http://konfederacjalewiatan. pl/aktualnosci/2015/1/wkrotce_decyzja_komisji_europejskiej_w_sprawie_zakazu_reklamy_aptek (access: 14.07.2017).

15 Prawo pacjenta do informacji a zakaz reklamy aptek, http://www.infor. $\mathrm{pl} /$ prawo/prawa-konsumenta/prawa-pacjenta/325381,2,Prawo-pacjenta-doinformacji-a-zakaz-reklamy-aptek.html (access: 14.07.2017).

${ }^{16}$ M. Kolasiński, op.cit. 
is a consistent approach that any kind of information the purpose of which is to encourage to purchase the goods offered by the pharmacy and which is treated like that by customers is regarded as an advertisement of a pharmacy ${ }^{17}$. The essence of this approach may comprise the theses included in the judgement justification of Supreme Administration Court of 26 June $2014^{18}$ that stated that any action made public and intended to increase the sales of medical products and medical goods offered by the pharmacy may be an advertisement of a pharmacy in the understanding of article 94a item 1 of Pharmaceutical Law. The real intention of the pharmaceutical entrepreneur undertaking the advertising activity is to persuade customers to buy products in a particular pharmacy ${ }^{19}$. Furthermore, it is not significant whether advertising is done inside or outside the pharmacy. Its advertising activity may be presented inside and outside the pharmaceutical premises. Thus, the provision of article 94a of Pharmaceutical Law does not indicate the borders of local advertising ${ }^{20}$. Similar explanations are included in other judgements of administration courts ${ }^{21}$.

The scope of advertising pharmaceutical activity is also interpreted as a reference to its perception by customers. The Supreme Court emphasised the fact that the group of medicine consumers consists in the majority of cases of sick people of lower capability

17 See among others, J. Adamski., K. Urban, E. Warmińska, Refundacja leków, środków spożywczych specjalnego przeznaczenia żywieniowego oraz wyrobów medycznych. Komentarz, Warszawa 2015; M. Kondrat, Prawo farmaceutyczne. Komentarz, Warszawa 2009; K. Jasińska, Reklama produktów leczniczych a reklama aptek, "Monitor Prawniczy" 2014, no 14; Decision of Supreme Administration Court of 5 March 2015, II GSK 541/14, Legalis no 1311065.

18 Decision of Supreme Administration Court of 26 June 2014, II GSK 668/13, Legalis no 1067735.

19 Also K. Jasińska, op.cit.

${ }^{20}$ Decision of Province Administration Court Warsaw of 7 August 2013, VI SA/Wa 1660/13, Legalis no 774081.

${ }^{21}$ For example: decision of Supreme Administration Court of 11 March 2015, II GSK 753/14, Legalis no 1248591; decision of Supreme Administration Court of 11 March 2015, II GSK 54/14, Legalis no 1217703; decision of Province Administration Court Warsaw of 6 October 2015, VI SA/Wa 34/15, Legalis no 1363402 . 
of perceiving things and making reasonable and critical evaluation, which also applies to the elderly people constituting a vast group of medicine-consumers. These people are more susceptible to suggestions and less critical. They are the target of the advertising, and the features of this group of recipients should be taken into consideration as a model of an average recipient while assessing the likelihood of confusion ${ }^{22}$. Decisions of the Court of Justice of the European Union present a different attitude concerning consumers of medicines. Patients are regarded as consumers showing a high level of attention as the purchased products affect their health ${ }^{23}$. Also some representatives of Polish doctrine claim that the purchaser of pharmaceutical products is a very careful consumer ${ }^{24}$. At the same time, it should be stated that the way how advertising is addressed to customers is not significant and it is not important if they are potential or real customers to recognize the advertising activity as the one infringing the prohibition assumed in article 94a item 1 of Pharmaceutical Law ${ }^{25}$. Advertising addressed to the public covers both advertising material towards which there is no doubt about its public scope ${ }^{26}$, as well as messages aimed at specialists, but for various reasons reaching people of no professional background in the medical branch ${ }^{27}$.

${ }^{22}$ Decision of Supreme Court of 2 October 2007, II CSK 289/07, "Orzecznictwo Sądu Najwyższego. Izba Cywilna” 2008, no 12, item 140, p. 54.

${ }^{23}$ Compare e.g. decision of SPI (second instance) of 13 February 2007, in case T-256/04 Mundipharma against OHIM - Altana Pharma (RESPICUR), http://eur-lex.europa.eu/legal-content/PL/TXT/?qid=1506941346345\&uri=C ELEX:62004TJ0256 (access: 02.10.2017 r.); decision of EU Court (first instance) of 15 December 2010 in case T-331/09 Novartis/OHIM against Sanochemia Pharmazeutika (TOLPOSAN), European Court Reports 2010 II-05967.

${ }^{24}$ R. Skubisz, Prawo znaków towarowych. Komentarz, Warszawa 1997, p. 90-91.

${ }^{25}$ Decision of Supreme Administration Court of 20 January 2015, II GSK 1718/13, Legalis no 1200112.

${ }^{26}$ E.g. presented on television, in the radio, published in generally available press, on the generally available websites, in a form of brochures, manuals, leaflets, posters.

${ }^{27}$ A. Rabiega-Przyłęcka, Glosa do wyroku WSA z 6.3.2008 r., VII SA/Wa 2216/07, LEX/el.2011. 
The broad perspective of understating advertising of the pharmaceutical activity is justified by the fact that the provision of article 94a item 1 of Pharmaceutical Law, apart from the statement that the information about the localisation and opening hours of a pharmacy or a pharmaceutical outlet does not constitute an advertisement, does not include a catalogue of actions which would be excluded ex lege from the scope of this term as it is in the case of an advertisement of a medical product ${ }^{28}$. The advertisement of pharmacies prohibited in the Polish system of Pharmaceutical Law may take various forms, in particular: phrases, slogans, TV spots, billboards, leaflets, folders or magazines given to the customers of a pharmacy ${ }^{29}$.

Without a doubt, the participation in a loyalty programmes is a form of advertising appearing the most frequently at the pharmaceutical market in trade practice. In principle, it is based on the cooperation agreement concluded between an entrepreneur running a pharmacy, and an facility performing the programme. Conclusion of this type of uncalled agreement is allowed pursuant to the principle of freedom of agreements assumed in the provision of article $353^{1}$ of the Civil Code. Without doubts, it is a bilaterally binding agreement. Thus, a pharmaceutical entrepreneur undertakes to: inform customers about the details of the programme indicating the window with marks showing that the pharmacy participates in the programme, submit the application forms, record points on participants' cards, give prizes chosen by patients, incur costs connected with the participation in the programme as well as make purchases of commercial goods in a specified amount in facilities belonging to a given chain. Moreover, a pharmacy allows to mark its premises with word and graphic trademarks of a specific loyalty programme. Whereas the facility performing the loyalty programme obliges itself to provide a pharmacy with cards, information materials and prizes.

${ }^{28}$ Decision of Supreme Administration Court of 11 March 2015, II GSK $753 / 14$, Legalis no 1248591.

${ }^{29}$ Decision of Supreme Administration Court of 5 March 2015, II GSK 54/14, Legalis no 1217703. 
The marketing programmes being the subject of the cooperation agreement are aimed to support the sale of medical products, medical materials and other goods. Having filled in the application form and received an individual card of a participant equipped with a barcode, the patient is entitled to participate in the programme. Patients receive acknowledgments for purchasing in a pharmacy in a form of small gifts i.e. - prizes. The right to receive a prize depends on the value of goods purchased in pharmacies participating in the programme. The points are recorded at the participant's card with the use of the barcode reader. The patient may choose a cataloguedisplayed prize awarded to them in exchange for the gathered points. The reception of a prize and an appropriate reduction of points gathered by a patient is recorded at the participant's card.

The loyalty programmes are assumed in the jurisdiction of the administrative courts to be a form of pharmacies advertising ${ }^{30}$. They are described as the ones to serve the purpose of attracting new customers and keeping the previous ones; they are also intended to increase sales by building loyalty among the most valuable current customers or be tools of consumer promotion used in sales where the customers are rewarded depending on the frequency of purchasing products or services of a given company and the amount of purchases ${ }^{31}$.

\section{Dispute over the prohibition to advertise pharmacies and pharmaceutical outlets}

The provision introducing the complete prohibition to advertise pharmacies and pharmaceutical outlets has become a cause of conflict of interests between the representatives of pharmaceuti-

\footnotetext{
30 See decision of Province Administration Court Warsaw of 27 March 2014, VI SA/Wa 3080/13, Legalis no 907749.

${ }^{31}$ Decision of Province Administration Court Warsaw of 11 September 2013, VI SA/Wa 1291/13, Legalis no 791615; Decision of Province Administration Court Warsaw of 17 September 2013, VI SA/Wa 1594/13, Legalis no 791701; Decision of Province Administration Court Warsaw of 5 March 2013, VI SA/Wa 2618/12, http://orzeczenia.nsa.gov.pl/doc/7960A9E2A9 (access: 14.07.2017)
} 
cal organisations and entrepreneurs running chains of pharmacies. There are also numerous judicial cases pending as a result of decisions given by the Provincial Pharmaceutical Inspectors telling the pharmaceutical entrepreneurs to stop advertising the pharmaceutical activity.

The proponents of maintaining article 94a of Pharmaceutical Law in the current sounding, in particular pharmacists focused around the Supreme Pharmaceutical Chamber, claim that the prohibition to advertise pharmacies healthcare public facilities status constitutes an important guarantee of the patient's protection. The relation between the patient and a pharmacists exercising a profession of public trust has to be based on full trust. According to the approach of the representatives of pharmaceutical organisations, patients cannot be endangered on the advertising influence which is aimed to increase the consumption of medicines, which is not indifferent for their health and life. Thus, a patient's welfare understood in a proper way should be anytime more appreciated and valued than the any profits of entrepreneurs. A medicine does not comprise "regular" goods. The patient cannot be treated in an instrumental manner; they cannot be encouraged to increase the consumption of medicines. The prohibition to advertise the activity of a pharmaceutical entrepreneur does not hinder the performance of the pharmacists profession; it, however, constitutes a guarantee for patients that the staff of a pharmacy shall thoroughly inform about medicines and their action and shall provide pharmaceutical care for the benefit of the patients themselves ${ }^{32}$.

On the other hand, the entrepreneurs assess the prohibition to advertise pharmacies as the excessive freedom restriction in terms of running the economic activity and the patient's access to information. The discrepancies arising from the lack of clear differentiation between the advertisement and the information introduce the uncertainty among the owners of pharmacies whether a particular action is subject to punishment or not. According to

32 The letter of the Supreme Pharmaceutical Chamber to the Prime Minister of 5 March 2014, http://www.old.nia.org.pl/news/2649/zakaz-reklamy-aptekbedacych-placowkami-ochrony.html (access: 14.07.2017). 
entrepreneurs, the prohibition of pharmacies advertising, understood as the prohibition to provide information about their activity, makes it impossible to promote the facilities that render services to customers at higher level which affects adversely the patients. Pharmacies which sell medicines without doctor's prescription, dietary supplements, hygienic products and dermo-cosmetics cannot advertise their activity although the advertisement of these products is not prohibited ${ }^{33}$. In practice the binding prohibition to advertise pharmacies makes it impossible for the Internet pharmacies to function efficiently ${ }^{34}$.

Taking into consideration the attitudes of the representatives of pharmaceutical organisations and the entrepreneurs running pharmaceutical chains, the further discussion should refer to the consistency of the provision of article 94a item 1 of Pharmaceutical Law with the Constitution of the Republic of Poland and in particular with the principle of freedom of economic activity.

\section{The prohibition to advertise pharmacies in view of constitutional principles of the freedom of economic activity}

Pursuant to article 20 of the Constitution of the Republic of Poland, social market economy based on the freedom of economic activity, private property and solidarity, dialogue and cooperation of social partners constitute the basics of the system of the Republic of Poland. The freedom of economic activity may be limited only in a way of an act due to an important public interest (article 22 of the Constitution of the Republic Poland).

In the decisions of the Constitutional Tribunal it is indicated that the freedom of economic activity mainly refers to the possibility to start and run activities aimed to achieve profit. The essence of the

${ }^{33}$ EU: Niekonstytucyjny zakaz reklamy aptek, "Rzeczpospolita” of 27.06.2013.

${ }^{34} \mathrm{~K}$. Nowosielska, Aptekarze walcza, by programy opieki farmaceutycznej nie byty zakazana reklama, "Rzeczpospolita" of 28.04.2015. 
freedom to run economic activity, understood as a public right, is a freedom of a subject of private right to start and run this activity. In contrast, both the bodies of public authorities as well as other subjects of law are obliged to refrain from interfering - in terms of legal or actual actions - in the area of free economy ${ }^{35}$.

A similar approach is represented by the academic - representatives of the economic law who regard the freedom of economic activity as so-called public right of "negative" character, which corresponds with the general obligation of the state on not infringing any freedom of beneficiaries of this right in terms of economic activity ${ }^{36}$. The competition of independent and autonomous economic facilities is a consequence of economic freedom. Sales transactions or any other kind of providing goods and services preconditions market existence of any entrepreneurs. As a result, the entrepreneurs are obliged to take actions which causes that it is their market offer, not the one of any other entrepreneurs, to be noticed and accepted by customers ${ }^{37}$. As the Supreme Court noticed, the competition is a beneficial economic factor providing progress and cost rationalisation and as a result also decrease in the product prices. The only prohibited competition is the unfair one based upon against-the-law activity and breaching good practices if it endangers or infringes the interest of another entrepreneur or customer ${ }^{38}$.

Pro-sales activities as a whole are specified as marketing and the advertisement is the most important instrument among the marketing techniques to attract a customer to the entrepreneur's offer. Due to this fact there cannot be any doubts that advertising

${ }^{35}$ See decision of the Constitutional Tribunal of 19 January 2010, SK 35/08, “Orzecznictwo Trybunału Konstytucyjnego" Series A 2010, no 2, item 16; decision of the Constitutional Tribunal of 7 June 2005, K 23/04, „Orzecznictwo Trybunału Konstytucyjnego" Series A 2005, no 6, item 62.

${ }^{36}$ A. Walaszek-Pyzioł, Swoboda działalności gospodarczej, Kraków 1994, p. $8-10$.

${ }^{37}$ The attitude of the Public Prosecutor General of 26 January 2016 in connection with a constitutional complain SK 23/15; http://trybunal.gov.pl/ sprawy-w-trybunale/katalog/s/sk-2315/ (access: 14.07.2017).

38 Decision of Supreme Court of 11 August 2004, II CK 487/03, LEX no 1761000 . 
is an indispensable element of economic activity, and the legislator's interference in this area is the interference into the freedom of running economic activity ${ }^{39}$. Thus, a question appears whether this interference is consistent with constitutional norms.

Assessing the constitutionality of provisions introducing the prohibition to advertise pharmacies and pharmaceutical outlets, it should be taken into consideration that pursuant to the rule of proportionality, the limitation of constitutional freedoms and rights of an individual has to be dictated by an important public interest and, moreover, it cannot infringe the essence of freedom or right ${ }^{40}$. The rule of proportionality included in the provision of article 31 item 3 of the Constitution of the Republic of Poland, orders to choose the measures, from the efficient measures limiting the use of freedom and rights, which are the least onerous for individuals ${ }^{41}$. The provision introducing the limitation is inconsistent with the Constitution if the same effects may be obtained with the use of measures which limit the use of freedom or rights in a smaller extent ${ }^{42}$.

The presentation of the position concerning the constitutionality of article 94a item 1 of the Pharmaceutical Law requires to conduct a proportionality test, which implies confronting a complained provision with the detailed rules of suitability, indispensability and proportionality sensu stricto.

${ }^{39}$ R. Skubisz, J Dudzik, Comment to article 18 u.z.n.k., in: Ustawa o zwalczaniu nieuczciwej konkurencji, Komentarz, ed. J. Szwaja, Warszawa 2013, Legalis.

40 Compare the decision of Constitutional Tribunal of 31 January 1996, K 9/95, “Orzecznictwo Trybunału Konstytucyjnego” 1996, no 1, item 2; decision of Constitutional Tribunal of 26 April 1995, K 11/94, „Orzecznictwo Trybunału Konstytucyjnego" 1995, item 12; as well as B. Banaszak, Konstytucja Rzeczypospolitej Polskiej. Komentarz, Warszawa 2012, Legalis.

${ }^{41}$ Pursuant to article 31 item 3 of the Constitution of the Republic of Poland, limitations in the scope of using constitutional freedom and rights may be established only in an act and only when they are necessary in a democratic country for its safety or public order or to protect the environment, health and public morality or freedom and rights of other persons. These limitations cannot infringe the essence of freedom and rights.

${ }^{42}$ The attitude of the Public Prosecutor General of 26 January 2016 in connection with a constitutional complain SK 23/15; http://trybunal.gov.pl/ sprawy-w-trybunale/katalog/s/sk-2315/ (access: 14.07.2017). 
In terms of the principle of suitability, the constitutionality test consists of determining whether the respective normative solution may lead to intended-by-it effects in line with the current knowledge ${ }^{43}$. In the decisions of the Constitutional Tribunal and in the doctrine it is assumed that the provisions which impede the achievement of aims or do not show any connections with these aims (are irrelevant) and fail to meet these conditions ${ }^{44}$. With consideration of suitability criterion solutions stipulated in article 94a item 1 of the Pharmaceutical Law, it is indicated that, as a rule, the prohibition to advertise pharmacies appears to be suitable for the achievement of the assumed objective, which is the reduction of medicines consumption, and in consequence - obtaining specific effects in terms of healthcare ${ }^{45}$. It should be emphasised that the excessive consumption of medical products undoubtedly affects health. Advertising any pharmaceutical entrepreneur's operations indicating lower prices or profitable discounts comes to contribute to purchasing and then consumption of medicines.

Conducting the test concerning the next criterion - the rule of principles of necessity - draws upon determining whether the tested provisions are indispensable for the protection of goods indicated in article 31 item 3 of the Constitution (and/or in article 22 of the Constitution) and besides that the least harmful measures were selected from all the measures protecting these values ${ }^{46}$. As the Constitutional Tribunal indicates, the application of this principle requires to consider alternative solutions which may be used and to specify their efficiency ${ }^{47}$. Referring the presented criterion to the solutions introduced by article 94a item 1 of pharmaceutical law, it should be stated that the introduction of the complete prohibition

43 Ibidem.

${ }^{44}$ Decision of Constitutional Tribunal of 23 November 2009, P 61/08, “Orzecznictwo Trybunału Konstytucyjnego” Series A 2009, no 10, item 150.

45 The attitude of the Public Prosecutor General of 26 January 2016 in connection with a constitutional complain SK 23/15; http://trybunal.gov.pl/ sprawy-w-trybunale/katalog/s/sk-2315/ (access: 14.07.2017).

46 Ibidem.

47 Decision of Constitutional Tribunal of 23 November 2009, P 61/08, “Orzecznictwo Trybunału Konstytucyjnego” Series A 2009, no 10, item 150. 
to advertise pharmacies seems to show the inconsequence of the legislator. It is difficult to perceive this prohibition as an indispensable measure aimed to decrease the consumption of medicines, especially in the situation when, at the same time, the marketing actions referring to medicines are allowed ${ }^{48}$. Thus, the provisions of Pharmaceutical Law limit the rights of medicine producers and facilities introducing the medical product at the Polish market primarily in a much smaller extent than the rights of facilities running pharmacies. Moreover, the provision of article 94a item 1 of Pharmaceutical Law may be regarded as a provision really limiting the freedom of competition. It is also important that the commercial offer of pharmacies usually includes a lot of products which are not medical products and no possibility to advertise a pharmacy in the scope of the sale of these products may force the facility running a pharmacy to limit the range of products in the offer for a customer ${ }^{49}$.

Thus, the presented considerations indicate that introducing the prohibition to advertise pharmacies and their activity, the legislator did not consider the possibility of using alternative measures and specification of their efficiency. It was possible to introduce the prohibition to run particular forms of marketing activity or the prohibition to use a given type of communication media ${ }^{50}$. The above considerations lead to the conclusion that article 94a item 1 does not meet the indispensable criterion of the limitation of rights and freedom included in it.

The last element of the proportionality test is to check whether the effects of article 94a of Pharmaceutical Law remain in an appropriate proportion to burdens imposed on a citizen by the provision. It is stated in the case-law that the assessment of meeting the

${ }^{48}$ Pursuant to article 52 item 1 of Pharmaceutical Law the activity consisting in informing or encouraging to use a medical product aimed to increase: the number of prescriptions, delivery, sale or consumption of medical products is an advertisement of a medical product.

49 The attitude of the Public Prosecutor General of 26 January 2016 in connection with a constitutional complain SK 23/15; http://trybunal.gov.pl/ sprawy-w-trybunale/katalog/s/sk-2315/ (access: 14.07.2017).

50 Ibidem. 
proportionality condition sensu stricto cannot occur in an abstract way but should be performed within the real situations indicated by a complained provision ${ }^{51}$. Assessing the provision of article 94a item 1 of Pharmaceutical Law concerning the proportionality principle sensu stricto, it should be stated that in the light of the Constitution of the Republic of Poland human healthcare is a value which, without doubts, entitles the legislator to interfere in the area of economic relations. The regulation included in the provision of article 94a item 1 of Pharmaceutical Law refers also to the issues connected directly with healthcare. However, it should be borne in mind that the available results of the test do not enable to acknowledge that the prohibition to advertise pharmacies is efficient ${ }^{52}$. The consumption of medicines increases every year ${ }^{53}$. In a consequence, considering the lack of correlation between relatively big rate of burden of the introduced limitations and effects achieved as a result of introducing the prohibition to advertise pharmacies, it should be acknowledged that the provision of article 94a item 1 of Pharmaceutical Law does not meet the condition of proportionality sensu stricto.

In conclusion, it should be stated that the complete prohibition to advertise pharmacies and their activity arising from article 94a item 1 of Pharmaceutical Law infringes the freedom of economic activity understood as the right of entrepreneurs running pharmacies to compete with other entrepreneurs running pharmacies in the scope of establishing the rules of selling goods and services

${ }^{51}$ Decision of Constitutional Tribunal of 23 November 2009, P 61/08, “Orzecznictwo Trybunału Konstytucyjnego" Series A 2009, no 10, item 150.

52 The position of the Public Prosecutor General of 26 January 2016 in connection with a constitutional complaint SK 23/15; http://trybunal.gov.pl/ sprawy-w-trybunale/katalog/s/sk-2315/ (access: 14.07.2017).

53 The accessible data show that in 2014 the sale of pharmaceutical products in Poland in 2014 was bigger than in the previous year. In particular, in 2014 the value of pharmaceutical market in Poland amounted to PLN 27.3 billion, i.e. by 3.3 billion more than in the previous year. The vast percentage of this amount - PLN 11.4 billion refers to medicines without a prescription. In 2014 as many as 680 million of packages of such substances were sold. See I. Sudak, My Polacy lekomani. Rekordowe wydatki na leki, groźne skutki reklam, "Gazeta Wyborcza” of 04.03.2015. 
by them, including shaping prices and the right of promotion and advertisement ${ }^{54}$. This prohibition infringes the rule of pharmacies and pharmaceutical outlets' freedom of business activity understood as maintaining the group of customers and acquiring new ones as well as using incentives to purchase not refunded products more cheaply by customers belongs to the essence of properly functioning company - a pharmacy.

\title{
STRESZCZENIE
}

\author{
Spór o zakaz reklamy działalności \\ przedsiębiorcy aptecznego
}

Usługi farmaceutyczne odnoszą się do rynku reglamentowanego, stanowią bowiem wyłączną domenę farmaceutów wykonujących tzw. medyczny zawód zaufania publicznego. $Z$ tego względu apteki jako placówki ochrony zdrowia publicznego podlegają rygorom odmiennym niż pozostałe podmioty gospodarcze. Jedno $z$ ograniczeń swobodnego prowadzenia działalności aptecznej stanowi przepis art. 94a ust. 1 Prawa farmaceutycznego, zgodnie $z$ którym zabroniona jest reklama aptek i punktów aptecznych oraz ich działalności; reklamy nie stanowi informacja o lokalizacji i godzinach pracy apteki lub punktu aptecznego. W praktyce stosowania powołanego przepisu często dochodzi do ograniczania przedsiębiorców aptecznych w zakresie swobody kształtowania własnej oferty handlowej. Celem niniejszego artykułu jest wyjaśnienie pojęcia oraz zakresu reklamy aptek, a także ustalenie, czy zakaz ten prowadzi do niekonstytucyjnego ograniczenia swobody działalności gospodarczej przedsiębiorcy prowadzącego aptekę.

Słowa kluczowe: reklama aptek; przedsiębiorca apteczny; swoboda działalności gospodarczej

54 The attitude of the Pharmaceutical Employers Association PharmaNET of 14 March 2013 concerning the draft of assumptions to the bill about the amendment of the law about medicine reimbursement, special purpose food agents and medical products and some other acts published by the Ministry of Health; https://legislacja.rcl.gov.pl/docs//1/161339/161340/161343/ dokument78597.pdf (access: 14.07.2017). 


\section{SUMMARY}

Dispute over the prohibition to advertise the activity of so called pharmaceutical entrepreneur

Pharmaceutical services refer to the regulated market, as they are the sole domain of pharmacists performing the so-called medical profession of public trust. Therefore, pharmacies as public health care facilities are subject to regulations different from other business facilities. One of the restrictions for a free pharmaceutical activity is Article 94a(1) of the Pharmaceutical Law, according to which it is prohibited to advertise pharmacies and pharmaceutical outlets and their activity; the information about the localization and opening time of a pharmacy or a pharmaceutical outlet is not treated as an advertisement. In the practice of applying this provision, pharmaceutical entrepreneurs are often limited in the scope of their own commercial offer. The objective of this article is a clarification of the concept of advertising pharmacies or pharmaceutical outlets and an attempt to resolve whether the prohibition to advertise pharmacies included in the provisions of the Pharmaceutical Law infringes the freedom of economic activity guaranteed to each entrepreneur pursuant to the Polish Constitution.

Keywords: advertising of pharmacies; pharmaceutical entrepreneur; freedom of economic activity

\section{BIBLIOGRAPHY}

Adamski J., Urban K., Warmińska E., Refundacja leków, środków spożywczych specjalnego przeznaczenia żywieniowego oraz wyrobów medycznych. Komentarz, Warszawa, 2015.

Banaszak B., Konstytucja Rzeczypospolitej Polskiej. Komentarz, Warszawa 2012.

Jasińska K., Reklama produktów leczniczych a reklama aptek, "Monitor Prawniczy" 2014, no 14.

Kolasiński M., Apteki: zakazy zamiast konkurencji, "Rzeczpospolita” of 18.11.2015.

Kondrat M., Prawo farmaceutyczne. Komentarz, Warszawa 2009. 
Kruszyński R., Podmiotowy i przedmiotowy zakres zakazu reklamy aptek $w$ znowelizowanym Prawie farmaceutycznym, "Aptekarz Polski” 2012, no 65.

Nowińska E., du Vall M., Ustawa o zwalczaniu nieuczciwej konkurencji. Komentarz, Warszawa 2010.

Nowosielska K., Aptekarze walcza, by programy opieki farmaceutycznej nie byty zakazana reklama, „Rzeczpospolita” of 28.04.2015.

Ogiegło L., Komentarz do art. 94a in: Prawo farmaceutyczne. Komentarz, L. Ogiegło (ed.), Warszawa 2015.

Ożóg M., System handlu produktem leczniczym i produktami pokrewnymi. Problematyka prawna, Warszawa 2010.

Rabiega-Przyłęcka A., Glosa do wyroku WSA z 6.3.2008 r., VII SA/Wa 2216/07, Lex/el.2011.

Skubisz R., Prawo znaków towarowych. Komentarz, Warszawa 1997.

Skubisz R., in: Ustawa o zwalczaniu nieuczciwej konkurencji. Komentarz, J. Szwaja (ed.), Warszawa 2013.

Sudak I., My Polacy lekomani. Rekordowe wydatki na leki, groźne skutki reklam, "Gazeta Wyborcza" of 04.03.2015.

Walaszek-Pyzioł A., Swoboda działalności gospodarczej, Kraków 1994. 
